\title{
Effect of seaweed saps concentrates on nutrient content in cane, leaves and nutrient uptake of sugarcane
}

N. LEINDAH DEVI AND S. MANI

\section{MEMBERS OF RESEARCH FORUM: \\ Corresponding author : N. LEINDAH DEVI, Department of Soil Science and Agricultural Chemistry, Tamil Nadu Agricultural University, COIMBATORE (T.N.) INDIA Email: leindahnong@gmail.com}

Co-authors :

S. MANI, Department of Soil Science and Agricultural Chemistry, Tamil Nadu Agricultural University, COIMBATORE (T.N.) INDIA Email: smainerode@ @rediff.com
Received : 02.08.2014; Revised : 29.09.2014; Accepted : 16.10 .2014

\section{Summary}

A field experiment on sugarcane was conducted in 2012-13 to study the effect of seaweed saps of Kappaphycus alverizii and Gracilaria spp. were tested at different concentrations $(2.5 \%, 5.0 \%, 6.25 \%, 7.5 \%$ and $10 \%)$ on nutrient content in cane, nutrient content in leaves and nutrient uptake by sugarcane. Significant improvement were observed in increasing nutrient content in cane, nutrient content in leaves and uptake by sugarcane at 10 per cent concentration of seaweed saps with recommended dose of fertilizer. Hence, the present study found that 10 per cent seaweed saps with recommended dose showed higher nutrient content in leaves, nutrient content in cane and nutrient uptake compared to other concentration.

Key words : Seaweed saps, Nutrient content, Leaves, Uptake, Sugarcane

How to cite this article : Devi, N. Leindah and Mani, S. (2014). Effect of seaweed saps concentrates on nutrient content in cane, leaves and nutrient uptake of sugarcane. Asian J. Soil Sci., 9(2): 196-202. 